\title{
EFFICACY OF SOME HERBICIDES ON WHEAT CROP AND ASSOCIATED WEEDS AND DETECTING ITS RESIDUES IN WHEAT PLANT AND SOIL. \\ Soliman, I.E. ${ }^{1}$ and Amany M. Hamza ${ }^{2}$
}

1. Weed Res. Cent. Lab., Agric. Res. Cent. El-Giza, Egypt.

2.Pesticides Dept., Fac. Agric. Kafr el sheikh Univ., 33516

Egypt.

\begin{abstract}
Two field experiments were conducted during the successive seasons of 2012/2013 and 2013/2014 at Sakha Agricultural Research Station to study the effect of SOME herbicides on wheat, NPK uptake, associated weeds and determine its residues in soil, leaves and grains of wheat plant. The results indicated that using the herbicides Granstar at $8.0 \mathrm{~g} / \mathrm{fed}$ for control broad-leaved weeds, Traxos at $0.5 \mathrm{~L} / \mathrm{fed}$ for control grassy weeds and Panther at $0.6 \mathrm{~L} / \mathrm{fed}$ and (Granstar/Traxos) for control annual weeds as applied post-emergence as well as hand weeding twice, gave excellent weed control.

Hand weeding treatment, Panther and (Granstar/Traxos) obviously increased plant height, spike length, weight of grains/spike, number of grains/spike, straw yield (ton/fed) and grain yield (ardab/fed) of wheat as compared with the control treatment. All herbicidal treatments as well as hand weeding treatment increased protein, phosphorus and potassium percentages and their uptake $(\mathrm{kg} / \mathrm{fed})$ in wheat grains over control treatment.

The times for $50 \%$ loss of initial Granstar in soil were 50.79 and 48.33 days. The loss of initial concentration in the leaves were $(0.29$ and $0.74 \mathrm{ppm})$ in the $1^{\text {st }}$ and $2^{\text {nd }}$ seasons, respectively. The Granstar residue become undetected in grains of the two growing seasons after 159 days from application. At the end of experiments about 97.73 and $97.32 \%$ of initial traxos in the soil in both seasons were lost. After 90 days, only 0.22 and $0.26 \mathrm{ppm}$ of Traxos were reached to the grains. At the end of experiment (145 days), there were no residues in the grains of the two growing seasons. The times for $50 \%$ loss of initial Panther in soil were 56.78 and 53.67 days and the loss of initial concentrations reached 97.32 and $98.84 \%$. At the end of the experiment (152 days) there were no Panther residues in wheat grains in the two growing seasons.

These results indicated that under heavy infestation with annual weed, it is possible to apply herbicides i.e. Panther and (Granstar/Traxos) treatments for annual weeds control, Granstar for broad-leaved weeds control and Traxos for grassy weeds control. These findings revealed obviously that such weed control measure can minimize weed/wheat competition and consequently gave the highest reduction in weeds and increase wheat yield, without any effect on wheat plants or on soil.
\end{abstract}

\section{INTRODUCTION}

In Egypt wheat (Triticum aestivum L.) has a special importance because the local production is not sufficient to supply the annual demands of the local requirements. Weeds are one of the most important problem in wheat production, which cause a highly loss in crop. The reduction of wheat yield due to weed infestation reached to $30.7 \%$ (Nisha et al., 1999). AlMarsafy et al. (1996) indicated that the losses in wheat yield due to grassy weeds reached about $44 \%$, meanwhile the losses in yield attributed to 
Phalaris spp. ranged from $40-50 \%$. Shaban et al. (2009) indicated that the reduction in wheat yield due to the broad-leaves weeds competition were 27.5 and $19.2 \%$; for grassy weeds 43.7 and $33.2 \%$, but for total annual weeds 46.8 and $46.4 \%$ in $2006 / 07$ and $2007 / 08$ seasons, respectively.

Weed control is one of the essential cultural practices for raising wheat yield and improving its quality. Chemical weed control in wheat fields by postemergence herbicides such as metosulam, tribenuron-methyl, clodinafob propargyl and isoproturon have been used to control weeds in wheat fields in Egypt to improve wheat productivity through elimination of weed competition (Al-Ashkar,1998; El-Metwally, 1999 Nagla and Soliman et al., 2011). However, the recommended dose of herbicides is relatively high and hence its cost price is too expensive under the Egyptian conditions. Jain et al. (1998) showed that the total weed population was reduced significantly with isoproturon. The greatest grain yield of 5.75 ton/ha was achieved with isoproturon at $1.875 \mathrm{~kg} / \mathrm{ha}$ and the lowest yield was produced from the untreated control (3.7 ton/ha). The combination of Brominal 24\% EC at 2.38 L/ha and Topic $15 \%$ wp at $333 \mathrm{~g} / \mathrm{ha}$ gave the highest reduction for the annual weeds and gave the highest value of wheat grain and straw yields as reported by Al-Marsafy et al. (1997), Hassanein et al. (1998) and Abd ElHamid and Ghalwash (2002). Mekky et al. (2010) found from Topic application at 70,140 and $210 \mathrm{~g} / \mathrm{fed}$. at 30 or 45 DAS of wheat that wheat was tolerant to the herbicide at recommended rate (140 g/fed) when applied at 45 DAS and very effective against canary grass and increased wheat production.

Walia and Kumar (2000) and Soliman et al. (2011) found that all herbicidal treatment (clodinafop propargyl, tribenuron-methyl and isoproturon) as well as hand weeding treatment increased protein, phosphorus, potassium and carbohydrate percentage and their uptake $\mathrm{kg} / \mathrm{fed}$ in wheat grains over control treatment.

Fakkar (1999 and 2005) showed that the application of Topic 24\% EC at $100 \mathrm{ccc}$ fed and hand weeding twice at 30 and 45 days after sowing had a significant effect on grain weight spike, spike length, the number of spikes/m2, 1000-grain weight, straw yield (ton/fed) and grain yield (ardab/fed) in wheat. Yasin et al. (2010) found that clodinafop (Topik-15 WG) at $37 \mathrm{~g}$ a.i./ha produced relatively less weed biomass, more plant height, number of spikes bearing tillers, number of grains/spike, 1000-grain weight and grain yield (4.20 ton/ha). Khan et al. (2011) indicated that Topik was effective in decreasing weed biomass and enhancing grain yield and its contributing traits.

The fate and behavior of herbicides in the soil are influenced by many factors, including soil properties, management, application methods, herbicide properties, landscapes, cultivated crops and climatic conditions. Also, the accumulation of herbicides in ground water is affected by physical, chemical and biological mechanisms (Ramesh and Balasubramanian, 1999). Melander et al. (2002) found that the residues of isoproluron in the wheat grain were 0.25 and $0.26 \mathrm{ppm}$ in both seasons, collected from treated plots contained 1.74 and $1.76 \mathrm{ppm}$. Ramesh and Beena (2008) estimated clodinafop propargyl residues by high performance liquid chromatographic 
(HPLC) technique. Limits of determination in grain and straw were 0.5 and 1.0 micro g/g, respectively. Harvest time residue in soil, wheat grain and straw were found to be below detectable limits. Singh et al. (2008) investigated the residues of isoproturon in soil, wheat grain and straw during harvest. Isoproturon was applied at $1.0 \mathrm{~kg}$ a.i./ha after 35 days of sowing wheat. They reported that the minimum detection limit of the herbicide in HPLC was 0.01 micro $\mathrm{g} / \mathrm{g}$. There was no detectable herbicide residue at the time of wheat harvest. Mitwally (2012) showed that the degradation of clodinafop propargyl, isoproturon and diclofop-methyl occurred faster in the field after 120-180 days of treatment. Abd El-Wahab et al. (2002) found that the time for $50 \%$ loss of initial Granstar (tribenuron-methyl) in soil were 50.97 and 49.33 days for Giza 164 and wheat cultivars Sids 7, repectively. The loss of initial Granstar concentration in leaves of Giza 164 and Sids 7 were (4.52 and $5.19 \mathrm{ppm}$ ). The Granstar residue became undetected in grains of the two varieties after 170 days after application. Fakkar et al. (2013) showed that there were no residues of herbicides (isoproturon, pyraflufen-ethyl and clodinafop-propargyl) as post-emergence herbicides on the tested wheat grains. However, detection residue for (diclofop-methyl) herbicide in wheat grain $(0.09 \mathrm{ppm})$ was lower than the maximum residue limits (MRL).

The objective of this work was to study the performance of some chemical and mechanical weed control treatments in wheat field. Consideration was given to their impacts on associated weeds and growth, nutrient uptake, yield components and yield of wheat. Attention was extended also to detect the residues of the applied herbicides in soil and plant parts of wheat plant.

\section{MATERIALS AND METHODS}

Two field experiments were performed at the experimental station, Sakha Agricultural Research Kafer el sheikh during the two successive winter seasons of 2012/2013 and 2013/2014 to study the effect of some herbicides on wheat crop, associated weeds and determination of its residues in wheat plants and soil. The experimental soil was clay in both seasons as shown in Table a.

Table a: Mechanical and chemical analysis of the experimental soils.

\begin{tabular}{|l|c|c|c|c|c|c|c|c|c|}
\hline Season & $\begin{array}{c}\text { Organic } \\
\text { matter } \%\end{array}$ & $\begin{array}{c}\text { Soil } \\
\text { pH }\end{array}$ & $\begin{array}{c}\text { Sand } \\
\%\end{array}$ & $\begin{array}{c}\text { Silt } \\
\%\end{array}$ & $\begin{array}{c}\text { Clay } \\
\%\end{array}$ & $\begin{array}{c}\text { Textural } \\
\text { class }\end{array}$ & $\begin{array}{c}\mathbf{N}, \\
\mathbf{p p m}\end{array}$ & $\begin{array}{c}\mathbf{P}, \\
\mathbf{p p m}\end{array}$ & $\begin{array}{c}\mathbf{K}, \\
\mathbf{p p m}\end{array}$ \\
\hline $2012 / 13$ & 1.35 & 8.29 & 18.72 & 33.73 & 48.4 & Clay & 22.00 & 20.00 & 280.92 \\
\hline $2013 / 14$ & 1.45 & 8.09 & 17.66 & 33.14 & 51.2 & Clay & 19.53 & 18.45 & 277.10 \\
\hline
\end{tabular}

Wheat grains (Triticum aestivum L.) cv. Sids 12 were used. The plot area was $3.0 \times 3.5 \mathrm{~m}$ (10.5 m2). The grains were broadcasted on the soil at a rate of $60 \mathrm{~kg} / \mathrm{fed}$ in Nov. 15 and 20 for the first and second seasons, respectively. The experiments were laid out in a complete randomized blocks design with four replications, where six treatments were used as follow:

1. Traxos (Clodinafop propargyl $2.25 \%$ + pinoxaden $2.25 \%$ + cloquintocet (sefener) $0.56 \% \mathrm{EC}$ ) at the rate of $0.5 \mathrm{~L} / \mathrm{fed}$ applied after 35 days from sowing. 
2. Granstar (tribenuron-methyl $75 \%$ DF) at the rate of $0.08 \mathrm{~kg} / \mathrm{fed}$ applied at 21 days after sowing.

3. Granstar at the rate of $0.08 \mathrm{~kg} / \mathrm{fed}$ applied at 21 days after sowing + Traxos at the rate of $0.5 \mathrm{~L} / \mathrm{fed}$ applied after 35 days from sowing.

4. Panther (isoproturon $50 \%$ + diflufencan $5 \% \mathrm{EC}$ ) at the rate of $0.6 \mathrm{~L} / \mathrm{fed}$. applied at 28 days after sowing.

5. Hand weeding twice (carried out at 30 and 50 days after sowing).

6. Control (untreated)

Herbicides in both field experiments were sprayed by Knapsack sprayer $\mathrm{CP}_{3}$ in water volume of 200 liters/fed. All agronomic practices in wheat such as land preparation, fertilization and irrigation were done as recommended during the two seasons of study. Nomenclature of herbicides are listed in Table b.

Table b: Nomenclature of the studied herbicides.

\begin{tabular}{|c|c|c|}
\hline Trade name & $\begin{array}{l}\text { Common } \\
\text { name }\end{array}$ & Chemical abstract name \\
\hline Traxos & $\begin{array}{c}\text { clodinafop } \\
\text { propargyl }+ \\
\text { pinoxaden }+ \\
\text { cloquintocet }\end{array}$ & $\begin{array}{l}\text { 8- ( } 2,6 \text { - diethyl }-p-\text { totyl })-1,2,4,5-\text { tetra hydro }-7- \\
\text { oxo }-7 \mathrm{~h}-\text { pyrozol }(1,2-\mathrm{d})[1,4,5]-\text { oxadiazelin }-9- \\
y \mathrm{l}-2,2-\text { dimethyl propionate. }\end{array}$ \\
\hline Granstar & $\begin{array}{c}\text { tribenuron- } \\
\text { methyl }\end{array}$ & $\begin{array}{c}\text { 2-[[[(4-methoxy-6-methyl-1,3,5-triazin-2-yl) } \\
\text { methylamino]carbonyl]amino]sulfonyl]benzoate. }\end{array}$ \\
\hline Panther & $\begin{array}{l}\text { isoproturon } \\
+ \text { diflufencan }\end{array}$ & $\begin{array}{c}2,4-\text { difluoro }-2-(\text { aaa }- \text { trifluoro } m-\text { tolyloxy }) \\
\text { nicotinanilide. }\end{array}$ \\
\hline
\end{tabular}

The collected data were recorded as follows:

\section{On weeds:}

Weeds were hand pulled at random from one square meter from each plot after 70 and 90 days from sowing and classified into two categories (broad-leaved and grassy weeds). The fresh weight of each species was estimated in $\left(\mathrm{g} / \mathrm{m}^{2}\right)$. Weed control\% was evaluated in the form of percent reduction (\%R) in the fresh weight of each individual groups of weeds as well as the total weeds according to Topps and Wain (1957) formula as following: $\% R=(A-B) / A \times 100$

Where:

$A=$ The fresh weight of weeds in untreated plot.

$B=$ The fresh weight of weeds in treated plot.

\section{Wheat growth characters and yield components:}

At harvest, samples of 10 wheat plants were randomly collected from each plot to estimate the following characters: plant height $(\mathrm{cm})$, spike length $(\mathrm{cm})$, weight and number of grains/spike. The straw yield (ton/fed) and grain yield (ardab/fed) were determined from yield of the whole plot.

\section{Chemical composition of wheat grains:}

Determination of total nitrogen, phosphorus and potassium were carried out on the ground dry material. The samples were digested in a mixture of sulfuric acid, salicylic acid and hydrogen peroxide according to Linder (1944). Total nitrogen content was estimated by Kjeldahl method (Ranganna, 1979). Phosphorus and potassium percentages in grains were determined according 
to Cottenie et al. (1982). Total carbohydrates were hydrolyzed using $1 \mathrm{~N}$ sulphuric acid and determined spectrophotometrically according to Dubois et al. (1956).

\section{Herbicides residues determination:}

The Granstar, Panther and Traxos herbicideswere sprayed after 21, 28 and 35 days from sowing, respectively. From each treatment plant parts and soil samples were taken after zero time (12 hours), 10, 30, 60, 90, 120 and $(159,152$ and 145) days after application, respectively. These samples were subjected to residues analysis of used herbicides in soil, leaves and grains. Extraction and determination of herbicides residues were carried out as follow:

\section{Extraction:}

Granstar, Panther and Traxos were extracted from leaves, grains and soil (50 g of each sample) according to the method of Klaus et al. (1974). All samples were cleaned up using sap-pale cartridge $\left(\mathrm{C}_{18}\right)$ according to the method of Ikebuchic et al. (1985).

\section{Determination:}

Residues of the three herbicides were determined using Beckman HPLC instrument fitted with variable wave length detector (119), $\mathrm{C}_{18}$ stainless steel column $(10 \times 250 \mathrm{~mm})$, dual pump for delivering solvent (110) and mobile phase water/methanol (10/90) for Granstar and (20/90) for Panther and Traxos, flow rate $(1 \mathrm{ml} / \mathrm{min})$. The retention time $(2.07 \mathrm{~min})$ for Ganstar $(2.85 \mathrm{~min})$ for panther and $(2.53 \mathrm{~min})$ for Traxos. The detection limit was 0.03 , 0.07 and 0.05 for Granstar, Panther and Traxos, respectively. The rate recovery of Granstar, Panther and Traxos were $97.88,95.13$ and $94.62 \%$ for each herbicide, respectively.

Statistical analysis:

The obtained data were subjected to proper statistical analysis of variance, according to Snedecor and Cochran (1980) and the least significant differences (LSD) at $5 \%$ level of significance were calculated. All statistical analysis was performed using analysis of variance technique by means of MSTATC computer software package.

\section{RESULTS AND DISCUSSION}

\section{Effect of weed control treatments: On weeds:}

The most dominant weeds accompanied with wheat plants were: Common bishops weed (Ammi majus), bur clover (Medicago hispida Gaerth), Chicory (Cichorium endivia L.) and annual sowthistle (Sonchus oleraceus L.) as a broad-leaved weeds, and rye grass (Lolium temulentum L.), little seed canary grass (Phalaris minor Retz) and wild oat (Avena spp.) as grassy weeds in both growing seasons.

Table 1 shows means of fresh weight of broad-leaved, grassy and total annual weeds of the two weed surveys as affected by different weed control treatments as compared with the control treatment in both seasons. At the first survey, all tested treatments significantly reduced the fresh weight of 
annual weeds as compared with control treatment. Clodinafop propargyl (Traxos) herbicide alone or in combination with Granstar gave the significantly highest reduction in fresh weight of grassy weeds in both seasons. Similar results are in agreement with those of Mekky et al. (2010) they reported that tribenuron-methyl (Granstar) decreased the fresh weight of broad-leaved weeds. While, isoproturon+diflufenican (Panther) and (Granstar followed by Clodinafop propargyl) treatment decreased the fresh weight of total annual weeds. Hand weeding treatment as well as foliar application of Panther and (Granstar / Traxos) gave higher efficiency in controlling annual weeds (90.85, 93.55 and 99.29\%). While, Traxos and Granstar herbicides alone gave the less effective control of total annual weeds (49.74 and $70.80 \%$ ) as compared with the control treatment in the first season .These results have the same trend in the second season.

Table 1: Effect of weed control treatments on fresh weight of annual weeds $\left(\mathrm{g} / \mathrm{m}^{2}\right)$ after 70 and 90 days from wheat sowing in 2012/13 and 2013/14 seasons.

\begin{tabular}{|c|c|c|c|c|c|c|c|}
\hline \multirow[b]{2}{*}{ Treatments } & \multirow[b]{2}{*}{ Rate/fed } & \multicolumn{3}{|c|}{70 days after sowing } & \multicolumn{3}{|c|}{90 days after sowing } \\
\hline & & $\begin{array}{l}\text { Broad } \\
\text { leaved } \\
\text { weeds } \\
\left(\mathrm{g} / \mathrm{m}^{2}\right)\end{array}$ & $\begin{array}{c}\text { Grassy } \\
\text { weeds } \\
\left(\mathrm{g} / \mathrm{m}^{2}\right)\end{array}$ & $\begin{array}{c}\text { Total } \\
\text { weeds } \\
\left(\mathrm{g} / \mathrm{m}^{2}\right)\end{array}$ & $\begin{array}{l}\text { Broad } \\
\text { leaved } \\
\text { weeds } \\
\left(\mathrm{g} / \mathrm{m}^{2}\right)\end{array}$ & $\begin{array}{c}\text { Grassy } \\
\text { weeds } \\
\left(\mathrm{g} / \mathrm{m}^{2}\right)\end{array}$ & $\begin{array}{c}\text { Total } \\
\text { weeds } \\
\left(\mathrm{g} / \mathrm{m}^{2}\right)\end{array}$ \\
\hline \multicolumn{8}{|c|}{$2012 / 13$} \\
\hline Traxos & $0.5 \mathrm{~L}$ & 1052.3 & 3.4 & 1055.7 & 2104.4 & 6.9 & 2111.3 \\
\hline Granstar & $0.08 \mathrm{~kg}$ & 10.2 & 604.1 & 614.3 & 18.5 & 938.5 & 957.0 \\
\hline Granstar/Traxos & $0.08 \mathrm{~kg} / 0.5 \mathrm{~L}$ & 9.2 & 5.6 & 14.8 & 12.6 & 14.6 & 27.2 \\
\hline Panther & $0.6 \mathrm{~L}$ & 89.3 & 46.3 & 135.6 & 158.4 & 86.6 & 245.0 \\
\hline Hand weeding & Twice & 92.6 & 99.7 & 192.3 & 134.9 & 190.7 & 325.6 \\
\hline Control (untreated) & & 1186.4 & 917.4 & 2103.8 & 2273.4 & 2827.4 & 5099.1 \\
\hline LSD at $5 \%$ & & 38.2 & 42.4 & 48.6 & 45.3 & 51.7 & 63.1 \\
\hline \multicolumn{8}{|c|}{$2013 / 14$} \\
\hline Traxos & $0.5 \mathrm{~L}$ & 1150.9 & 7.8 & 1158.7 & 2168.9 & 23.7 & 2192.6 \\
\hline Granstar & $0.08 \mathrm{~kg}$ & 32.6 & 762.8 & 795.4 & 53.7 & 1062.8 & 1116.5 \\
\hline Granstar/Traxos & $0.08 \mathrm{~kg} / 0.5 \mathrm{~L}$ & 16.8 & 25.5 & 42.3 & 32.6 & 43.7 & 76.3 \\
\hline Panther & $0.6 \mathrm{~L}$ & 103.5 & 166.5 & 270.0 & 182.5 & 127.3 & 309.8 \\
\hline Hand weeding & Twice & 215.6 & 292.6 & 508.2 & 154.7 & 282.6 & 436.9 \\
\hline Control (untreated) & & 1736.6 & 1312.8 & 3149.4 & 2542.5 & 2113.3 & 4655.8 \\
\hline LSD at $5 \%$ & & 45.2 & 45.1 & 52.0 & 44.8 & 52.9 & 56.7 \\
\hline
\end{tabular}

At the second survey, the same trend for controlling total annual weeds was observed. Hand weeding treatment, Panther and (Granstar/Traxos) as post-emergence reduced the fresh weight of total annual weeds by 93.61 , 95.15 and $99.46 \%$ in the first season and $90.60,93.34$ and $98.48 \%$ in the second season compared with control treatment. The superiority of these treatments in controlling weeds could be attributed to the continuous destroying effect of the sequential application of treatment during vegetative growth. Similar results were obtained by Nagla Al-Ashkar (1998) and Mekky et al. (2010). 


\section{On wheat yield components:}

Data presented in Table 2 indicated that all tested treatments increased significantly wheat plant height than control treatment. (Granstar/Traxos), hand weeding and Panther gave the high values and significantly increased plant height of wheat at harvest in both seasons, respectively. The reduction in plant height under the control treatment could be attributed to the negative effect of weeds competition on growth of wheat.

Concerning spike length, data in Table 2 shows that spike length is significantly affected by all treatments at harvest during the two growing seasons. In general, all weed control treatments significantly surpassed control treatment. Spike length values ranged from 7.7 to $14.2 \mathrm{~cm}$ in the frist season and $7.1-13.8 \mathrm{~cm}$ in the second season. The longest spike length was obtained by (Granstar/Traxos), hand weeding and Panther. While, the significantly shortest spike length was achieved with the control treatment. These results are similar to those obtained by Metwally and Hassan (2001).

Table 2: Effect of weed control treatments on wheat yield components at harvest in 2012/13 and 2013/14 seasons.

\begin{tabular}{|c|c|c|c|c|c|}
\hline Treatments & Rate /fed & $\begin{array}{l}\text { Plant } \\
\text { height } \\
\text { (cm) }\end{array}$ & $\begin{array}{l}\text { Spike } \\
\text { length } \\
\text { (cm) }\end{array}$ & $\begin{array}{c}\text { Wt. of } \\
\text { grains/spike } \\
\text { (g) }\end{array}$ & $\begin{array}{c}\text { No. of } \\
\text { grains/spike }\end{array}$ \\
\hline \multicolumn{6}{|c|}{$2012 / 13$} \\
\hline Traxos & $0.5 \mathrm{~L}$ & 90.3 & 8.9 & 2.5 & 41.7 \\
\hline Granstar & $0.08 \mathrm{~kg}$ & 95.8 & 9.1 & 3.1 & 44.6 \\
\hline Gransta/Traxos & $0.08 \mathrm{~kg} / 0.5 \mathrm{~L}$ & 119.5 & 14.2 & 3.7 & 58.2 \\
\hline Panther & $0.6 \mathrm{~L}$ & 110.4 & 10.8 & 3.2 & 48.6 \\
\hline Hand weeding & Twice & 115.2 & 11.2 & 3.3 & 50.8 \\
\hline Control (untreated) & & 83.6 & 7.7 & 0.8 & 29.18 \\
\hline LSD at $5 \%$ & & 5.12 & 2.14 & 1.15 & 5.44 \\
\hline \multicolumn{6}{|c|}{$2013 / 14$} \\
\hline Traxos & $0.5 \mathrm{~L}$ & 97.7 & 8.4 & 2.2 & 42.8 \\
\hline Granstar & $0.08 \mathrm{~kg}$ & 103.5 & 9.7 & 2.4 & 45.4 \\
\hline Gransta/Traxos & $0.08 \mathrm{~kg} / 0.5 \mathrm{~L}$ & 118.2 & 13.8 & 3.8 & 59.6 \\
\hline Panther & $0.6 \mathrm{~L}$ & 111.4 & 12.1 & 2.7 & 48.1 \\
\hline Hand weeding & Twice & 113.7 & 11.7 & 2.8 & 52.4 \\
\hline Control (untreated) & & 80.9 & 7.1 & 0.7 & 22.8 \\
\hline LSD at $5 \%$ & & 4.36 & 2.01 & 1.16 & 5.07 \\
\hline
\end{tabular}

Data recorded in Table 2 revealed that significant differences between treatments in weight and number of grains/spike at harvest in both growing seasons. Generally, all weed control treatments significantly increased weight and number of grains/spike compared to control treatment. The highest values of weight and number of grains/spike were obtained from (Granstar/Traxos), hand weeding and Panther treatments. This could be attributed to the higher weed control efficiency (Table 1). On the other side, the lowest number and weight of grains/spike was obtained from control treatment. This might be due to the detrimental impact of weed competition on growth and photosynthetic activity of wheat plants. While, the herbicide Traxos and Granstar alone were in between. Similar results were reported by Nagla Al-Askar (1998) and El-Metwally et al. (1999. 


\section{On wheat yield:}

Data in Table (3) show that all weed control treatments significantly produced higher straw yield (ton/fed) than control treatment. The highest straw yield/fed was obtained from (Granstar/Traxos), hand weeding and Panther treatments, respectively, followed by the herbicide Traxos and Granstar alone compared to the control treatment. Such superiority might be due to the increase in plant height at the harvest as a result of better weed control in the two seasons. In contrast, the lowest straw yield/fed was obtained from control treatment. Similar results were obtained by El-Metwally et al. (1999) who reported that post-emergence application of isoproturon as well as hand weeding treatment increased the straw yield in wheat compared with the control treatment.

Table 3: Effect of weed control treatments on wheat grain and strow yields at harvest in 2012/13 and 2013/14 seasons.

\begin{tabular}{|c|c|c|c|c|c|}
\hline \multirow[b]{2}{*}{ Treatments } & \multirow[b]{2}{*}{ Rate /fed } & \multicolumn{2}{|c|}{$2012 / 13$} & \multicolumn{2}{|c|}{$2013 / 14$} \\
\hline & & $\begin{array}{c}\text { Straw yield } \\
\text { (ton/fed) }\end{array}$ & $\begin{array}{l}\text { Grain yield } \\
\text { (ardab/fed) }\end{array}$ & $\begin{array}{c}\text { Straw yield } \\
\text { (ton/fed) }\end{array}$ & $\begin{array}{l}\text { Grain yield } \\
\text { (ardab/fed) }\end{array}$ \\
\hline Traxos & $0.5 \mathrm{~L}$ & 3.79 & 13.18 & 3.61 & 13.26 \\
\hline Granstar & $0.08 \mathrm{~kg}$ & 3.98 & 14.76 & 3.87 & 14.62 \\
\hline Gransta/Traxos & $0.08 \mathrm{~kg} / 0.5 \mathrm{~L}$ & 4.89 & 18.88 & 4.86 & 18.52 \\
\hline Panther & $0.6 \mathrm{~L}$ & 4.36 & 17.56 & 4.29 & 17.28 \\
\hline Hand weeding & Twice & 4.52 & 17.42 & 4.42 & 17.76 \\
\hline Control (untreated) & & 1.82 & 9.33 & 1.78 & 9.74 \\
\hline LSD at $5 \%$ & & 0.92 & 2.39 & 0.80 & 2.03 \\
\hline
\end{tabular}

Data presented in Table 3 showed that grain yield (ardab/fed) was affected by different weed control treatments during the two growing seasons. Grain yield/fed of all the applied weed control treatments significantly exceeded the control treatment. It is evident that, the best treatments were (Granstar/Traxos), hand weeding and Panther, respectively, followed by Granstar and Traxos alone. These treatments significantly increased grains yield/fed about by $50.58,46.75,46.56,29.21$ and $36.79 \%$ in the first season over the control treatment, respectively. The same trend was presented in second season. These increases might be mainly due to the higher weed control efficiency for the previous treatments (Table 1), and also to their significant positive effects in raising grain yield per unit area and its related components such as spike length, weight of grains/spike and number of grains/spike (Table 2) leading to the higher grain yield/fed. While, the lowest grain yield/fed. was obtained from control treatment as a resultant of the competition between wheat and weed plants for the essential environmental resources i.e., light, water and nutrients. These results are in harmony with those obtained by Mekky et al. (2010) and Soliman et al. (2011). They reported that hand weeding treatments as well as foliar application of isoporutron or Topik gave the highest grain yield of wheat compared to the control treatment.

On nutrient uptake:

Data in Table (4) show that the uptake of N, P, K \% and $(\mathrm{kg} / \mathrm{fed})$ in wheat grains yield was higher and significant with all weed control treatments 
as compared with control treatment. These results were true as an average of the two seasons. The highest percentage of N,P and $\mathrm{K}$ were obtained from (Granstar/Traxos) treatment, Panther and hand weeding. These superiority are attributed to minimizing weed competition which in turn increased the availability of these elements to wheat plants uptake as compared with wheat plants which accompanied with weeds which share these plants in nutrient uptake. These results confirmed the negative effects of weeds on wheat yield. Similar results were obtained by Varsheney and Singh (1990) and Soliman et al. (2011), they found that isoproturon, clodinafap propargyl and hand weeding twice reduced uptake of $\mathrm{N}, \mathrm{P}$ and $\mathrm{K}$ by weeds by $54-60 \%$.

Table 4: Effect of weed control treatments on NPK \% and uptake $(\mathrm{kg} / \mathrm{fed})$ of wheat grains in $2012 / 13$ and $2013 / 14$ seasons.

\begin{tabular}{|c|c|c|c|c|c|c|c|}
\hline \multirow[t]{2}{*}{ Treatments } & \multirow[t]{2}{*}{ Rate/fed } & \multirow[t]{2}{*}{ N\% } & \multirow[t]{2}{*}{$\mathbf{P} \%$} & \multirow[t]{2}{*}{$\mathrm{K} \%$} & \multicolumn{3}{|c|}{$\begin{array}{c}\text { Absolute amount } \\
(\mathrm{kg} / \mathrm{fed})\end{array}$} \\
\hline & & & & & $\mathbf{N}$ & $\mathbf{P}$ & $\mathbf{K}$ \\
\hline \multicolumn{8}{|c|}{$2012 / 13$} \\
\hline Traxos & $0.5 \mathrm{~L}$ & 1.78 & 0.254 & 0.519 & 10.16 & 4.96 & 34.73 \\
\hline Granstar & $0.08 \mathrm{~kg}$ & 1.82 & 0.247 & 0.528 & 12.06 & 5.64 & 40.93 \\
\hline Gransta/Traxos & $0.08 \mathrm{~kg} / 0.5 \mathrm{~L}$ & 2.14 & 0.356 & 0.624 & 16.68 & 9.60 & 56.86 \\
\hline Panther & $0.6 \mathrm{~L}$ & 2.07 & 0.298 & 0.583 & 14.44 & 7.38 & 50.86 \\
\hline Hand weeding & Twice & 2.02 & 0.277 & 0.567 & 14.10 & 6.91 & 49.81 \\
\hline Control (untreated) & & 1.35 & 0.141 & 0.231 & 2.91 & 1.77 & 16.62 \\
\hline \multicolumn{8}{|c|}{$2013 / 14$} \\
\hline Traxos & $0.5 \mathrm{~L}$ & 1.83 & 0.264 & 0.528 & 10.46 & 5.21 & 36.00 \\
\hline Granstar & $0.08 \mathrm{~kg}$ & 1.86 & 0.256 & 0.536 & 12.11 & 5.74 & 41.73 \\
\hline Gransta/Traxos & $0.08 \mathrm{~kg} / 0.5 \mathrm{~L}$ & 2.15 & 0.373 & 0.640 & 16.85 & 5.75 & 57.03 \\
\hline Panther & $0.6 \mathrm{~L}$ & 2.04 & 0.298 & 0.582 & 14.19 & 7.23 & 50.06 \\
\hline Hand weeding & Twice & 2.05 & 0.274 & 0.564 & 14.18 & 6.84 & 51.03 \\
\hline Control (untreated) & & 1.44 & 0.161 & 0.237 & 3.11 & 2.14 & 19.14 \\
\hline
\end{tabular}

\section{Determination of herbicides residues in soil and leaves and grains of wheat plants:}

Data in Tables 5 and Fig. 1 showed the residual behavior of Traxos (clodinafop propargyl + pinoxaden + cloquintocet) in soil and leaves and grains of wheat plant under field conditions. At zero time (35 days after sowing), the concentration of Traxos in the soil were 16.32 and $15.67 \mathrm{ppm}$ in the first and second seasons, respectively. After 60 days about 55.76 and $54.95 \%$ of the initial Traxos concentration in the soil of the two seasons, respectively were degradated, and at the end of experiment about 97.73 and $97.32 \%$ of initial Traxos in the soil in both seasons were decomposed. The time for $50 \%$ loss of initial Traxos in soil was shorter in the first season than the second season (55.73 and 57.21 days). The persistence of Traxos in the grains became detectable after 120 days from application. On the other hand, the concentration of Traxos at zero time in leaves were 9.43 and $8.32 \mathrm{ppm}$ in the two seasons, respectively. After 30 days of application Traxos residue losses were 48.36 and $48.68 \%$ of initial Traxos in the leaves of both growing seasons and after 60 days, the Traxos residue became 2.21 and $2.08 \mathrm{ppm}$ (about 76.56 and $75.0 \%$ loss of initial Traxos) in the leaves of the two growing 
seasons, respectively. The half lives of Traxos in leaves were 31.44 and 41.52 days for the first and second seasons, respectively, under field conditions. So, Traxos was useful to control weeds without any residues in strow and grains of wheat. Marshal et al. (1996) reported that the wheat was identified by its rapid uptake and subsequent degradation of ${ }^{14} \mathrm{C}$-tralkoxydim (within $6 \mathrm{~h}$ ) in the treated leaves. After 120 days only 0.07 and $0.09 \mathrm{ppm}$ of Traxos reached to the grains of the first and second seasons, respectively. On the other hand, about 99.26 and $98.92 \%$ of initial Traxos in leaves in both seasons were disappeared by degradation. At the end of experiment (145 days), there were no Traxos residue in the grains of the two growing seasons.

Table 5: Stability of Traxos (clodinafop propargyl + pinoxaden + cloquintocet) herbicide in soil and leaves and grains of wheat plants under field conditions (ppm) in 2012/13 and 2013/14 seasons.

\begin{tabular}{|c|c|c|c|c|c|c|}
\hline \multirow{2}{*}{$\begin{array}{l}\text { Samples time } \\
\text { (days) }\end{array}$} & \multicolumn{6}{|c|}{$2012 / 13$} \\
\hline & Soil & Loss $\%$ & Leaves & Loss $\%$ & Grains & Loss $\%$ \\
\hline Zero & 16.32 & - & 9.43 & - & - & - \\
\hline 10 & 13.17 & 19.30 & 9.31 & 33.09 & - & - \\
\hline 30 & 11.54 & 29.29 & 4.87 & 48.36 & - & - \\
\hline 60 & 7.22 & 55.76 & 2.21 & 76.56 & - & - \\
\hline 90 & 4.19 & 74.33 & 0.62 & 93.43 & 0.22 & 96.29 \\
\hline 120 & 2.13 & 86.95 & - & - & 0.07 & 99.26 \\
\hline 145 & 0.37 & 97.73 & - & - & UND & 100.0 \\
\hline \multirow[t]{2}{*}{ T 0.5 (days) } & \multicolumn{2}{|c|}{55.73} & \multicolumn{2}{|c|}{31.44} & \multicolumn{2}{|c|}{40.65} \\
\hline & \multicolumn{6}{|c|}{$2013 / 14$} \\
\hline Zero & 15.67 & - & 8.32 & - & - & - \\
\hline 10 & 12.33 & 21.31 & 6.11 & 26.56 & - & - \\
\hline 30 & 10.46 & 33.25 & 4.27 & 48.68 & - & - \\
\hline 60 & 7.06 & 54.95 & 2.08 & 75.00 & - & - \\
\hline 90 & 4.01 & 74.41 & 0.67 & 91.95 & 0.26 & 96.88 \\
\hline 120 & 2.10 & 86.60 & - & - & 0.09 & 98.92 \\
\hline 145 & 0.42 & 97.32 & - & - & UND & 100.0 \\
\hline T 0.5 (days) & \multicolumn{2}{|c|}{57.21} & \multicolumn{2}{|c|}{41.52} & \multicolumn{2}{|c|}{59.13} \\
\hline
\end{tabular}

Zero: after 12 hours from application

UND: Undetectable

T 0.5: half lives 


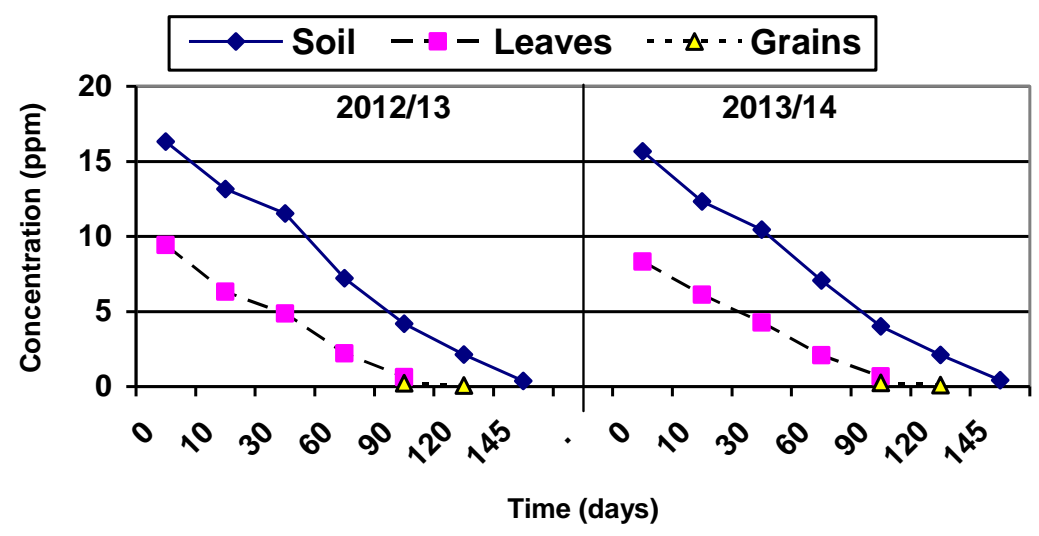

Fig. 1: Stability of Traxos (clodinafop propargyl + pinoxaden + cloquintocet) herbicide in soil and leaves and grains of wheat plant under field conditions (ppm) in 2012/13 and 2013/14 growing seasons.

Tables 6 and Fig. 2 showed that the behavior of Granstar in soil, leaves and grains of wheat plants. The concentration of Granstar in soil after application (zero time) was (12.48 and $14.32 \mathrm{ppm}$ ) for the first and second seasons, respectively. The time for $50 \%$ loss of initial Granstar in soil were ( 50.79 and 48.33 days) for the two seasons, respectively and reached to about 0.18 and $0.19 \mathrm{ppm}$ or (98.56 and $97.67 \%$ loss) after 159 days from application for the two seasons, respectively. There was no obviously different between the rate of degradation constant of Granstar in the two seasons, and its degradation should correspond to greater microbial and enzymatic soil activities. These findings are in agreement with those of Berger et al. (1998) they reported that the natural production of citric acid by the fungus, caused decreasing in $\mathrm{pH}$ followed by chemical hydrolysis of herbicides. About 8.17 and $9.58 \mathrm{ppm}$ were found in leaves of the first and second season, respectively, at zero time ( 21 days after sowing), then after 30 days the concentration of Granstar in leaves were 4.26 and $4.62 \mathrm{ppm}$ or (47.86 and $51.77 \%$ loss) of the initial Granstar concentration in the leaves of the first and second season, respectively, and reached to about (96.45 and $92.28 \%$ loss) after 90 days in the two seasons, respectively. Only 0.06 and $0.06 \mathrm{ppm}$ of Granstar were detected after 120 days from application in grains of the two seasons, respectively. So, about (99.27 and $99.37 \%$ loss) of initial Granstar concentration in the leaves of the two seasons by degradation during 120 days. After 159 days, the Granstar residue became undetected in grains of the two seasons. These results are in agreement with those of Reuchaud et al. (1991) as they detected diflufenican herbicide and its metabolites residue in the grain of wheat and they found that none of these compounds was never detected in the flour after harvest. 
Table 6: Stability of Granstar (tribenuron-methyl) herbicide in soil and leaves and grains of wheat plants under field conditions (ppm) in 2012/13 and 2013/14 seasons.

\begin{tabular}{|c|c|c|c|c|c|c|}
\hline \multirow{2}{*}{$\begin{array}{l}\text { Samples time } \\
\text { (days) }\end{array}$} & \multicolumn{6}{|c|}{$2012 / 13$} \\
\hline & Soil & Loss $\%$ & Leaves & Loss $\%$ & Grains & Loss $\%$ \\
\hline Zero & 12.48 & - & 8.17 & - & - & - \\
\hline 10 & 11.72 & 6.09 & 6.12 & 25.09 & - & - \\
\hline 30 & 9.28 & 25.64 & 4.26 & 47.86 & - & - \\
\hline 60 & 4.34 & 65.52 & 2.17 & 72.58 & - & - \\
\hline 90 & 2.28 & 81.73 & 0.29 & 96.45 & 0.19 & 97.67 \\
\hline 120 & 1.28 & 89.74 & - & - & 0.06 & 99.27 \\
\hline 159 & 0.18 & 98.56 & - & - & UND & 100.0 \\
\hline \multirow[t]{2}{*}{ T 0.5 (days) } & \multicolumn{2}{|c|}{50.79} & \multicolumn{2}{|c|}{36.98} & \multicolumn{2}{|c|}{62.89} \\
\hline & \multicolumn{6}{|c|}{$2013 / 14$} \\
\hline Zero & 14.32 & - & 9.58 & - & - & - \\
\hline 10 & 13.47 & 0.94 & 7.02 & 26.72 & - & - \\
\hline 30 & 10.22 & 28.63 & 4.62 & 51.77 & - & - \\
\hline 60 & 5.42 & 62.15 & 2.70 & 71.82 & - & - \\
\hline 90 & 2.67 & 81.35 & 0.74 & 92.28 & 0.21 & 97.81 \\
\hline 120 & 1.46 & 98.80 & - & - & 0.06 & 99.37 \\
\hline 159 & 0.19 & 98.67 & - & - & UND & 100.0 \\
\hline T 0.5 (days) & \multicolumn{2}{|c|}{48.33} & \multicolumn{2}{|c|}{37.23} & \multicolumn{2}{|c|}{65.57} \\
\hline
\end{tabular}

Zero: after 12 hours from application

UND: Undetectable

T 0.5: half lives

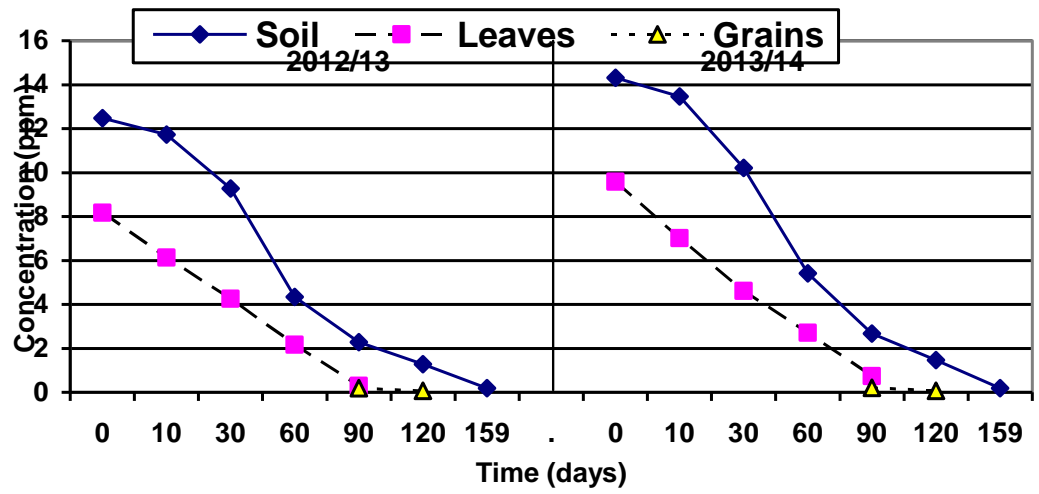

Fig. 2 : Stability of Granstar (tribenuron-methyl) herbicide in soil and leaves and grains of wheat plants under field conditions (ppm) in 2012/13 and 2013/14 growing seasons

Table 7 and Fig. 3 showed the behavior of Panther (isoproturon + diflufencan) herbicide in soil and leaves and grains of wheat plants under field conditions. The concentration of Panther in soil after application (zero time) was 17.62 and $15.12 \mathrm{ppm}$ for the first and second seasons, respectively. The time for $50 \%$ loss of initial Panther in soil were 56.78 and 53.67 days for the two growing seasons, respectively and reached to about 
0.18 and 0.19 ppm concentration or 97.32 and $98.74 \%$ loss after 152 days from application for the two seasons, respectively.

The concentration of Panther at zero time (28 days after growing) in leaves were about 10.57 and $8.87 \mathrm{ppm}$ in the first and second seasons, respectively. After 30 days of application Panther residue in leaves were 4.96 and $4.23 \mathrm{ppm}$ or $53 . .07$ and $52.31 \%$ loss of the initial Panther concentration in the leaves of the first and second seasons, respectively, and became 93.47 and $91.88 \%$ loss after 90 days in the two growing seasons, respectively. Only 0.09 and $0.11 \mathrm{ppm}$ of Panther were detected after 120 days of application in grains of the first and second seasons, respectively. So, about 99.15 and $98.76 \%$ loss of the initial Panther concentration was detected_in the leaves of the two growing seasons by degradation during 120 days.

Table 7: Stability of Panther (isoproturon + diflufencan) herbicide in soil and leaves and grains of wheat plants under field conditions (ppm) in 2012/13 and 2013/14 seasons.

\begin{tabular}{|c|c|c|c|c|c|c|}
\hline \multirow{2}{*}{$\begin{array}{l}\text { Samples time } \\
\text { (days) }\end{array}$} & \multicolumn{6}{|c|}{$2012 / 13$} \\
\hline & Soil & Loss $\%$ & Leaves & Loss $\%$ & Grains & Loss $\%$ \\
\hline Zero & 17.62 & - & 10.57 & - & - & - \\
\hline 10 & 15.73 & 10.73 & 7.32 & 30.75 & - & - \\
\hline 30 & 12.32 & 30.08 & 4.96 & 53.07 & - & - \\
\hline 60 & 8.44 & 52.10 & 2.07 & 80.42 & - & - \\
\hline 90 & 4.15 & 76.45 & 0.69 & 93.47 & 0.34 & 96.78 \\
\hline 120 & 2.23 & 89.48 & - & - & 0.09 & 99.15 \\
\hline 152 & 0.18 & 97.32 & - & - & UND & 100.0 \\
\hline \multirow[t]{2}{*}{ T 0.5 (days) } & \multicolumn{2}{|c|}{56.78} & \multicolumn{2}{|c|}{28.02} & \multicolumn{2}{|c|}{33.82} \\
\hline & \multicolumn{6}{|c|}{$2013 / 14$} \\
\hline Zero & 15.12 & - & 8.87 & - & - & - \\
\hline 10 & 13.32 & 11.90 & 6.12 & 31.00 & - & - \\
\hline 30 & 9.02 & 40.34 & 4.23 & 52.31 & - & - \\
\hline 60 & 6.37 & 57.87 & 2.10 & 76.32 & - & - \\
\hline 90 & 3.97 & 73.74 & 0.72 & 91.88 & 0.44 & 95.04 \\
\hline 120 & 2.11 & 86.04 & - & - & 0.11 & 98.76 \\
\hline 152 & 0.19 & 98.74 & - & - & UND & 100.0 \\
\hline T 0.5 (days) & \multicolumn{2}{|c|}{53.67} & \multicolumn{2}{|c|}{25.91} & \multicolumn{2}{|c|}{30.32} \\
\hline
\end{tabular}

Zero: after 12 hours from application

UND: Undetectable

$T$ 0.5: half lives

After 152 days, the Panther residue became undetectable in leaves of the two growing seasons. These results are in agreement with those of Mitwally (2012) he found that the residues of Cldinafop-propargyl and isoproturon were not detected in the soil after 150 days from application at the recommended rates. 


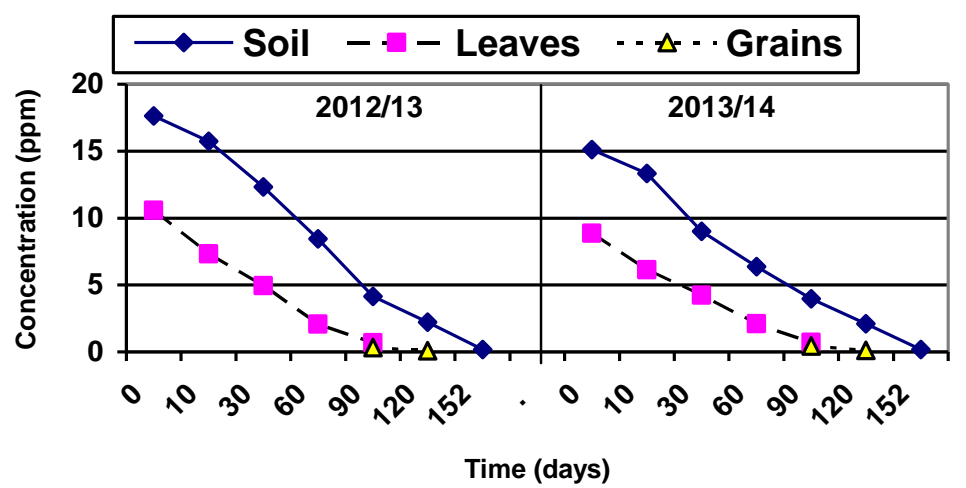

Fig. (3): Stability of Panther (isoproturon + diflufencan $n$ ) herbicide in soil and leaves and grains of wheat plants under field conditions (ppm) in 2012/13 and 2013/14 growing seasons.

From the previous results, it could be deduced that Traxos, Granstar and Panther herbicides degraded rapidly during planting of wheat in soil, leaves and grains. They were active herbicides against annual weeds in wheat fields. Therefore, the previous herbicides can be recommended safely for using at the rate of application as spraying for wheat plants without any toxic residues in either soil or grains and strow of wheat crop.

\section{REFERENCES}

Abd El-Hamid, M.M. and A.M. Ghalwash (2002). Effect of weed control on grassy weeds in wheat fields. Nile Valley Regional Program for Wild Oats Control in Cereals and Some Other Winter Crops. Egypt $10^{\text {th }}$ Ann. Meet. Cairo, 22-24 Sept., 164-168.

Abd El-Wahab, H.; Soad A. Ibrahim; M.F.R. El-Bouze and M.H. Kamel (2002). Determination of tralkoxydim and tribenuron-methyl in wheat plant, soil and its effect on aphids infestation and on fresh yield. J. Agric. Sci. Mansoura Univ., 27(5): 3495-3509.

Al-Marsafy, H.T.; A.N. Nassar; A.A. Esmail and A.A. Fakkar (1996). Effect of weed/wheat competition on wheat. $4^{\text {th }}$ Annual Meeting of Nile Valley Regional Program for Wild Oat Control in Cereals and Some Other Winter Crops. Egypt, 15-19 Sept., Cairo, 231-233.

Al-Marsafy, H.T.; A.S. Kholosy and A.N. Nassar (1997). Potential of hand weeding and herbicides sequences on controlling wild oats under heavy infestation conditions. Nile Valley Regional for Wild Oat Control in Cereals and Some Other Winter Crops. Egypt, $5^{\text {th }}$ Ann. Coordination Meet, Cairo, 11-15, Sept., 145-149.

Berger, B.M.; K. Janowitz; H.J. Menne and H.H. Hoppe (1998). Zeitschrift für pflanzen krankeiten und pflanzenschutz, 105(6): 611-623

Cottenie, A.; M. Vrloo; L. Kiekens; G. Velghe and R. Camerlynik (1982). Chemical analysis of plant and soils. Lab. of Analytical and Agrochemistry Stat Univ. Ghent, Belgium, P. 15-17. 
Dubois, M.; K.A. Gelles; J.K. Hamition and P.A. Aebers (1956). Colourimetric method for determination of sugars and related substances. Anal. Chem., 28: 350-356.

El-Metwally, G.M.; E.R. El-Desoki and A.E. Abedallah (1999). Effect of some post-emergence herbicides on wheat yield and associated weeds. J. Agric. Sci. Mansoura Univ., 24(12): 7215-7224.

Fakkar, A.A.O. (1999). Studies on weed control in wheat. M.Sc. Thesis, Fac. Agric., Assiut Univ., Egypt.

Fakkar, A.A.O. (2005). Efficiency of some weed control methods under different levels of nitrogen fertilizers in wheat. Ph.D. Thesis, Fac. Agric., El-Minia Univ., Egypt.

Fakkar, A.A.O.; I.A. Amin and A.M.A. Hassanein (2013). Maximizing wheat productivity by using some improved sowing methods and weeding treatments. Bull. Fac. Agric., Cairo Univ., 64: 269-289.

Hassanein, E.E.; M.M. Abd El-Hamid; A.H. Gonima and A.M. El-Shaler (1998). Integrated wild oats control in wheat in New Land in El-Banger zone. Nile Valley Regional Program for Wild Oats Control in Cereals and Some Other Winter Crops. Egypt $6^{\text {th }}$ Ann. Coordination. Meet., Cairo, 6-11 Sept., 1-12.

Ikebuchic,J.; S. Katoka; M. Ohtia and K. Okada (1985). Thin layer chromatography with flame ionization detector using a rapid seppake cartedge extraction. Eisei Kagaka, 31(2): 141 - 144. ( C. F. STN International).

Jain, M.P.; R.S. Lidder and K.K. Jain (1998). Weed management in wheat (Triticum aestivum L.). World Weeds, 5(1-2): 15-30.

Khan, B.M.; M.A. Khan; S. Hashim; K. Nawab and A.M. Khattak (2011). Integrated weed management in wheat. Pakistan. J. Bot., 43(1): 625-633.

Klaus, R.; D.H. Wolf and O.E. Dicta (1974). Multiresidue method for the determination of triazine herbicide in field crop grown agriculture crops, water and soil. J. AOAC, 57(1): 192-201.

Linder, R.C. (1944). Rapid analytical methods for some of the more common inorganic constituents of plant tissues. Plant Physiol., 19(1): 76.

Marshal, G.; J. Gemell; R.C. Kirkwood; G.E. Leach; I.B. Bryan; S.T. Hadfield; A.R. Jutsum; H. Brown; G.W. Cussans; M.D. Devine; S.O. Duke; C. Fernandez-Quintanilla; A. Helweg; R.E. Labrada; M. Landes; P. Kudsk and J.C. Streibig (1996). Possible mechanisms conferring selectivity to tralkoxudim. Proceedings of the Second International Weed Control Congress, Copenhagen, Denmark, 25-28 June, Vol. 1-4, pp. 833-838

Mekky, M.S.; E.E. Hassanein; M.R. Moshtohry; A.S. Kholosy and A.M. Hassanein (2010). Wheat and barley tolerance and three common grassy weed susceptibility to clodinafop-proprgyl. Egypt. J. Agric. Res., 88(10): 719-727.

Melander, B.; A. Cirujeda and M.H. Jorgensen (2002). Effect of inter-row hoeing and fertilizer placement on weed growth and yield of winter wheat. European Weed Research Society Weed Research, 43: 428-438

Metwally, G.M. and A.A.A. Hassan (2001). Efficacy in adding urea or ammonium Sulphate on herbicides efficiency in controlling weeds in wheat crop. J. Agric. Sci. Mansoura Univ., 26 (6): 2435 - 3446. 
Mitwally, W.A. (2012). Compatibility between some agricultural fertilizers and herbicides in wheat plantations, with special reference to their environmental effects. Ph.D.Thesis (Botany and Chemistry) Ain Shams Univ., Egypt.

Nagla, M.A. Al-Ashkar (1998). New herbicides on wheat growth and associated weeds. M.Sc. Thesis, Fac. Agric., Cairo Univ., Egypt.

Nisha, C.; S. Harpal; H.P. Tripathi; N. Chopra and H. Singh (1999). Critical period of weed crop competition in wheat (Triticum aestivum L.). Indian J. of Weed Sci., 31(3-4): 151-154.

Ramesh, A. and M. Balasubramanian (1999). Kinetics and hydrolysis of fenamiphos, fipronil and tifluralin in aqueous buffer solutions. J. Agric. Food Chem., 47(8): 3367-3371.

Ramesh, K. and K. Beena (2008). Persistence of clodinafop-propargyl in soil and wheat crop. Environment and Ecology, 26 (48): 2149-2151.

Ranganna, S. (1979). Manual of Analysis of Fruit and Vegetable Products. Tata McGraw Hill Publishing Company Limited, New Delhi, 364 pp.

Reuchaud, J.; F. Gustin; M. Van Himme; R. Bulcke; F. Benoit and K. Maddons (1991). Metabolism of the herbicide diflufenican in the soil of field wheat crop. J. Agric. Food Chem., 39: 968-976.

Shaban, Sh.A.; S. Soliman; Z.R. Yehia and M.H. El-Attar (2009). Weed competition effect on some (Triticum aestivum) quality and quantity components. Egypt. J. Agron., 31(2): 135-147.

Singh, D.K.; G. Singh; A. Srivastava and N.K. Sand (2008). Harvest time residue of isoproturon in soil, wheat grain and straw. Pantnagar $\mathrm{J}$. of Res., 6(1): 125-127

Snedecor, G.W. and W.G. Cochran (1980). Statistical Methods $6^{\text {th }}$ Ed., lowa State Univ. Press, Ames, USA, 325-330.

Soliman, I.E.; G.M. Abd El-Hamid and A.M. Fadl-Allah (2011). Effect of herbicides and urea as additive on wheat, nutrient uptake, photosynthetic pigments and associated weeds. J. Plant Production, Mansoura Univ., 2(1): 1393-1407.

Srivastava, A.; K.C. Gupta and G. Singh (1995). Dissipation of tralkoxydim herbicide from wheat crop and soil under subtropical conditions. Pestic. Sci., 43(1): 53-55.

Topps, J.H. and R.L. Wain (1957). Investigation of fungitoxicity of 3 and 5-alkyl saliclanilids and parachloro aniline. Ann. Appli. Biol., 45(3): 506-511.

Varsheney, J.G. and H.G. Singh(1990). Effect of Adjuvants on herbicide efficacy in controlling weeds in wheat. Weed sci. 38 (3): $229-236$.

Walia, U.S. and N. Kumar (2000). N-uptake by wheat and Phalaris minor as influenced by irrigation and weed control treatments. Environment and Ecology, 18(1): 134-137.

Yasin, M.; A. Tanveer; Z. Igbal and A. Ali (2010). Effect of herbicide on narrow leaved weeds and yield of wheat (Triticum aestivum L.). World Academy of Science, Egineering and Technology, 44: 1290-1292. 


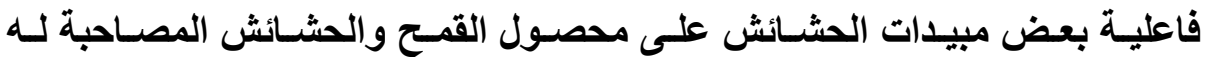

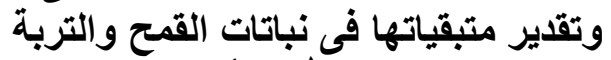

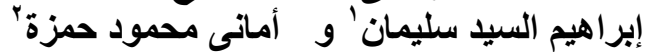

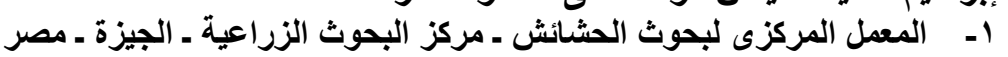

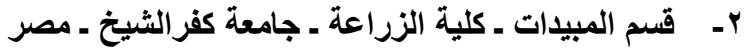

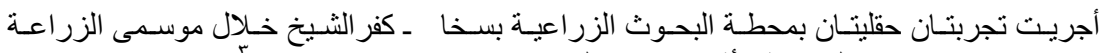

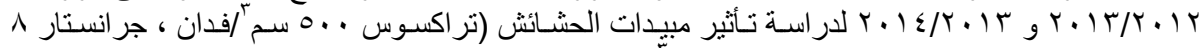

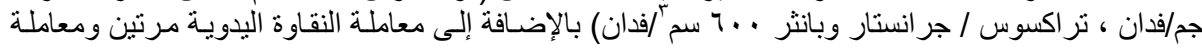

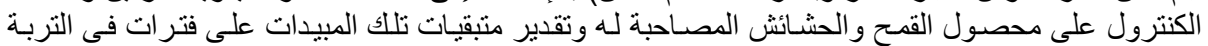

$$
\text { وأوراق وحبوب القمح وقد أظهرت النتائج ما يلى }
$$

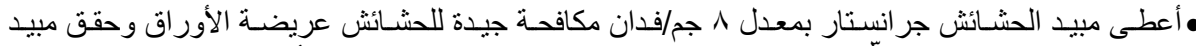

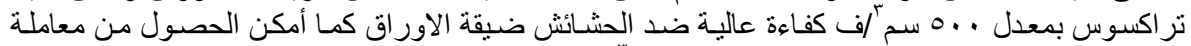

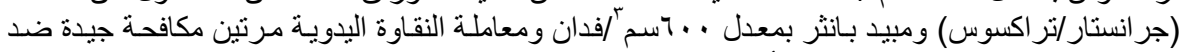

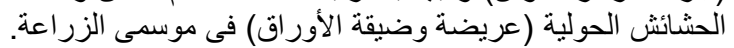

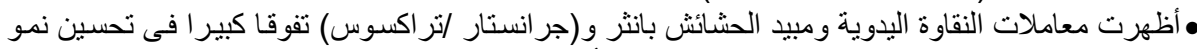

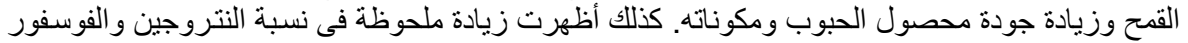
و البوتاسيوم فى حبوب القمح مقارنة بمعاملة الكنترول.

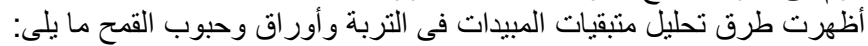

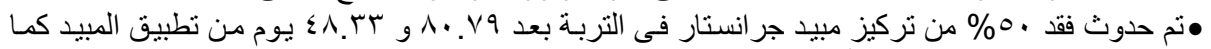

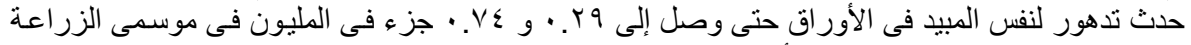

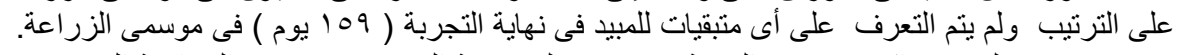

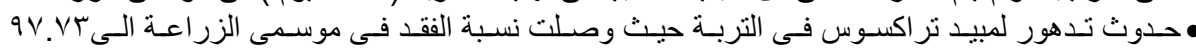

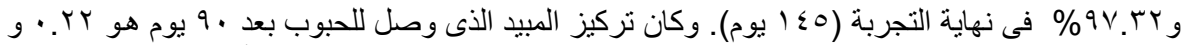

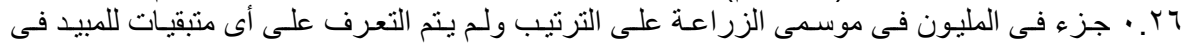

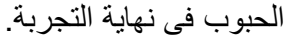

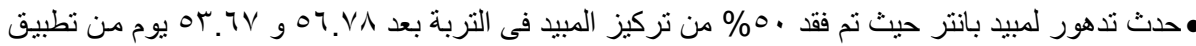

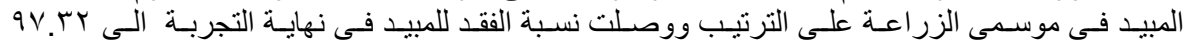

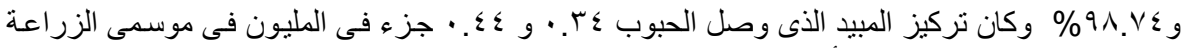

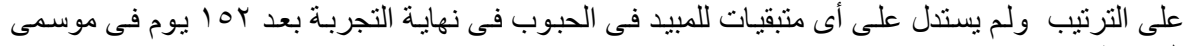
لذا توصى هذه الدراسة بإمكانية مكافحة الحشائش فى حقول القمح بمبيدات الحشائش كالتالى: مبيد

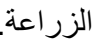

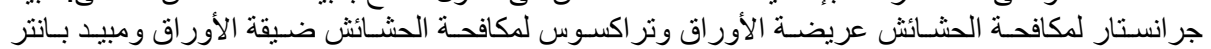

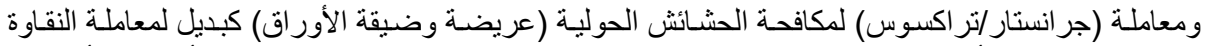

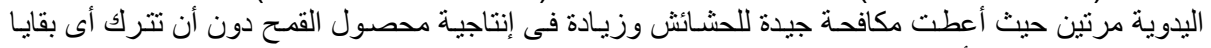

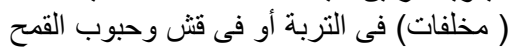

